\title{
Breeding melon for resistance to Fusarium wilt: recent developments
}

\author{
A. Oumouloud - M. El-Otmani - H. Chikh-Rouhou • \\ A. Garcés Claver • R. González Torres • R. Perl-Treves • \\ J. M. Álvarez
}

Received: 3 December 2012/ Accepted: 28 February 2013/Published online: 15 March 2013

(C) The Author(s) 2013. This article is published with open access at Springerlink.com

\begin{abstract}
Melon Fusarium wilt (MFW), caused by Fusarium oxysporum f. sp. melonis (Fom), is one of the most destructive diseases of melon (Cucumis melo L.). The development and deployment of resistant cultivars is generally considered to be the best approach to control MFW. Based on the host resistance genes associated with variants of this pathogen, Fom isolates were classified into four physiological races designated $0,1,2$, and 1,2. Two dominant resistance genes, Fom-1 and Fom-2, control resistance to races 0 and 2, and 0 and 1, respectively. Fom isolates classified as race 1,2 are able to induce disease in melon lines carrying the above resistance genes. Many sources of resistance to Fom races 0, 1, and 2 have been reported. Partial resistance to race 1,2 controlled by polygenic recessive genes was only detected in a few Far Eastern melon accessions, except for the breeding line BIZ where complete resistance was described. Identification of
\end{abstract}

A. Oumouloud $(\varangle) \cdot$ M. El-Otmani

Institut Agronomique et Vétérinaire Hassan II, Agadir BP. 121, km 2, Route de Taroudant, 80150 Ait Melloul,

Morocco

e-mail: aoumouloud@aragon.es

A. Oumouloud $\cdot$ H. Chikh-Rouhou .

A. G. Claver · R. G. Torres - J. M. Álvarez

Centro de Investigación y Tecnología Agroalimentaria

de Aragón, 93050080 Zaragoza, Spain

R. Perl-Treves

Mina and Everard Goodman Faculty of Life Sciences,

Bar-Ilan University, 52900 Ramat Gan, Israel
DNA markers tightly linked to genes conferring resistance to Fom has immediate application in MFW resistance breeding programs. The Fom-2 gene has been cloned, and it encodes a protein with a nucleotide binding site (NBS) and leucine-rich repeats domain (LRR). Based on the sequence of this domain, some molecular markers linked to this gene were developed. Several DNA markers linked to Fom- 1 have also been described. However, the usefulness of these markers was variety-dependent. Therefore, their combined use would be very useful in marker assisted selection for introducing resistance to Fom races 0 and 2 in melon. Recently, these markers were used for the positional cloning of this gene, which encoded a protein with a NBS-LRR domains that shows similarity to the toll and interleukin-1 receptores (TIR). Regarding Fom race 1,2, nine QTL were detected on five linkage groups by composite interval mapping. In this paper we review the current knowledge of MFW disease, and focus on genetic resistance to Fom and marker-assisted selection for resistance.

Keywords Fusarium oxysporum f. sp. melonis . Cucumis melo $\cdot$ Race $\cdot$ Gene $\cdot$ QTL . Molecular markers

\section{Introduction}

Melon (Cucumis melo L.) is an important horticultural fruit crop in tropical and subtropical regions, but it is 
also grown extensively in temperate zone countries. World production of cantaloupes and other melons in 2009 was about 26 million tons (www.fao.org). As many other crops, melon is susceptible to numerous foliar and root fungal pathogens that induce disease and reduce yield and fruit quality. Among these, Fusarium wilt is caused by a soil-borne pathogen, Fusarium oxysporum Schlechtend: Fr. f. sp. melonis (H.N. Hansen) W.C. Snyder \& H.N. Hans (Fom). This fungus survives in the soil as chlamydospores, and is capable of colonizing crop residues and roots of most crops grown in rotation with melon (Gordon et al. 1989). Therefore, crop rotation has only provided limited protection against melon Fusarium wilt (MFW) disease (Crino et al. 2007).

Soil disinfection using various chemical products mainly methyl bromide (Cebolla et al. 2000) was a traditional practice to control Fom in greenhouses. Because of environmental and human health concerns (Brimner and Boland 2003), this fumigant was banned in industrialized countries. Developing countries have a different methyl bromide control schedule mandating a $20 \%$ reduction in 2005 and total phase-out by 2015 (Gullino et al. 2003).

Soil solarization is another effective strategy to reduce soil inoculum and control wilt disease (Tamietti and Valentino 2006), but is not readily applicable for intensive vegetable farming systems, where time required to solarize the soil is very limited. Furthermore, soil solarization is often limited by local climate constraints such as temperature and relative humidity (Shlevin et al. 2004). Grafting of melons onto resistant rootstocks is also considered a promising practice to control soil-borne diseases in vegetables, particularly for MFW (Cohen et al. 2002; King et al. 2008). However, the added cost still limits its feasibility only to melon varieties with great economic value.

The use of resistant cultivars, therefore, is probably the most effective and practical means of controlling MFW. The success of breeding programs for MFW resistance is influenced by many factors, including: the nature of the pathogen and diversity of virulence in the population; availability, diversity and type of genetic resistance; or the effectiveness of methods and tools, such as molecular markers, used for assessing plant resistance.

The objective of this paper is to review the present state of knowledge on the MFW disease, the existing sources of genetic resistance, and the availability and usefulness of molecular markers and quantitative trait loci (QTL) linked to resistant to Fom. Such knowledge of is needed to develop resistant cultivars to this disease.

\section{Pathogen and pathogenesis of MFW}

Species, races and vegetative compatibility groups

Fusarium oxysporum Schlechtendahl emend. Snyder and Hansen is a cosmopolitan species (Booth 1971) comprising both pathogenic and nonpathogenic isolates (Gordon and Martyn 1997). The pathogenic isolates of $F$. oxysporum cause Fusarium wilt on several agricultural crops, and are accordingly subdivided into formae speciales (Snyder and Hansen 1940; Baayen 2000).

One of the economically more important and destructive $f$. speciales is the causal agent of MFW, F. oxysporum f. sp. melonis Snyder and Hansen (Leach and Currence 1938). The first report of MFW in New York was in 1930 (Chupp 1930), and it later has been found in many melon-growing areas worldwide, including America (Leach and Currence 1938), Europe, Asia (Quiot et al. 1979; Sherf and Macnab 1986), and Africa (Schreuder et al. 2000). The nature of the diversity comprised within Fom has direct bearing on the prospects for MFW control through genetic resistance; therefore a range of approaches are typically employed for the characterization of Fom isolates.

In general, to define genetic relationships within $f$. speciales, $F$. oxysporum strains have been grouped into vegetative compatibility groups (VCGs) based on their ability to form heterokaryons (Puhalla 1985). Strains that belong to the same VCG normally have identical alleles at their compatibility loci, enabling the exchange of nuclear material (Glass et al. 2000). In Fom, Jacobson and Gordon (1990a) identified eight VCGs: 0130, 0131, 0132, 0133, 0134, 0135, 0136 and 0137 , in a worldwide collection of Fom isolates. Also, various DNA-based tools have been used to separate Fom into a number of clonal lineages that more or less correspond to their VCG grouping (Jacobson and Gordon 1990b; Namiki et al. 1998).

Currently, variation in virulence within a $f$. speciales has been categorized by assigning pathotypes to 
pathogenic races. Races are defined by their differential interaction with host genotypes (Armstrong and Armstrong 1978), which, in some cases, are cultivars known to carry one or more major genes for resistance. Fom isolates have been divided into four common races designated as $0,1,2$ and 1,2 (Table 1), based on pathogenicity on three melon differential cultivars, 'Charentais-T', 'Doublon' and 'CM-17187' (Risser et al. 1976). The resistance genes effective against the respective races have been characterized in these differential cultivars: 'Doublon' and 'CM-17187' possess single dominant resistance genes, Fom-l and Fom-2, respectively; 'Charentais-T' has no known resistance gene. The race nomenclature corresponds to the resistance genes that are overcome (Risser et al. 1976). Race 1,2 overcomes these two resistance genes and is further divided into pathotype $1,2 \mathrm{y}$, which induces leaf yellowing symptoms before the death of the plants, and 1,2w, which causes wilting and death without prior yellowing symptoms (Bouhot 1981). More recently, race 1,2 has spread through the world (Veloso et al. 2000; Perchepied and Pitrat 2004; Herman and Perl-Treves 2007). The spread of this race has become a problem for melon cultivation, and the development of genotypes with resistance to multiple races of the pathogen represents a major objective in melon breeding programs. Until recently, only a few cultivars (hybrids) tolerant to race 1,2 have been available commercially, and they are mainly used as rootstocks.

\section{Origin of pathogenic races}

In general terms, the appearance of a new Fom race, as might be evidenced by a previously resistant cultivar succumbing to the disease, could be explained in one of two ways: either the new race was introduced from another geographic area, or it originated locally. The latter scenario may be explained either by derivation from a preexisting race, through selection pressure for virulence by extensive spread of resistant cultivars, or by selecting from the local population of non-pathogenic strains of $F$. oxysporum. A good example of introduction from distant areas is Fom race1/VCG 0134, that is known to occur in Europe (Jacobson and Gordon 1990a), Central Asia (Mohammadi et al. 2004), North America (Jacobson and Gordon 1990a), and South Africa (Schreuder et al. 2000). Molecular markers, including mitochondrial (Jacobson and Gordon 1990b) and nuclear DNA haplotypes (Appel and Gordon 1995), confirm that VCG 0134 corresponds to a clonal lineage. Thus, identified infestations of race 1/VCG 0134 in California (Gwynne et al. 1997), Maryland (Jacobson and Gordon 1990a), New York (Zuniga and Zitter 1993), and South Africa are very likely the result of introduction from areas where the race was already established.

Although movement of strains as a result of human activities is clearly dominant in the establishment of new infestations of MFW, de novo origin of pathogenic forms is also possible. Several lines of evidence support this view. First, in these $f$. speciales, there is a complex relationship between pathogenic races and VCGs (or clonal lineages). That is, a given race may be associated with more than one VCG and some VCGs are associated with multiple races. For example, VCG 0134 of Fom is associated with all four known races. Furthermore, races 0,1 , and 1,2 , are all associated with identical mtDNA (Jacobson and Gordon 1990b) and nuclear DNA haplotypes (Schroeder and Gordon 1993). The close relationship between these three different races may indicate that relatively simple genetic changes can lead to a change in cultivar specificity, i.e. one pathogenic race can give rise to another.

Factors such as co-evolution with the plant host and the spread of virulence determinants via processes
Table 1 Classification of Fusarium oxysporum f. sp. melonis races based on Risser et al. (1976)

[R] and [S] indicate resistance and susceptible phenotype respectively

\begin{tabular}{llll}
\hline $\begin{array}{l}\text { Fusarium oxysporum f. sp. } \\
\text { melonis races }\end{array}$ & \multicolumn{4}{l}{ Differential cultivars and their gene for resistance } \\
\cline { 2 - 4 } & Charentais-T & Doublon $($ Fom-1) & CM-17187 (Fom-2) \\
\hline Race 0 & {$[\mathrm{~S}]$} & {$[\mathrm{R}]$} & {$[\mathrm{R}]$} \\
Race 1 & {$[\mathrm{~S}]$} & {$[\mathrm{S}]$} & {$[\mathrm{R}]$} \\
Race 2 & {$[\mathrm{~S}]$} & {$[\mathrm{R}]$} & {$[\mathrm{S}]$} \\
Race 1,2 & {$[\mathrm{~S}]$} & {$[\mathrm{S}]$} & {$[\mathrm{S}]$} \\
\hline
\end{tabular}


such as parasexuality, heterokaryosis, and sexual recombination have also been implicated in the evolution of this pathogen (Gordon and Okamoto 1992; Guadet et al. 1989). Although parasexuality and heterokaryosis are known to occur in F. oxysporum (Beckman and Roberts 1995), sexual fruiting structures have never been observed in the species and only indirect evidence for sexual recombination has been detected (Snyder and Hansen 1940).

\section{Molecular methods for Fom detection} and quantification

Current methods used for Fom detection include visual observation of disease symptoms, fungal mycelia and spores (Baayen 2000), as well as isolation of the fungus using a selective culture medium (Komada 1975). Because the selective medium is not species- or strain-specific, proper identification can be timeconsuming and non-definitive, and results are not immediately available due to the time required for fungal growth. Molecular methods based on polymerase chain reaction (PCR), such as real-time PCR, offer advantages over classical detection methods because they are sensitive, reliable, and quick (Schena et al. 2004).

More recently, López-Mondéjar et al. (2012) developed and validated a real-time PCR method that allowed detection and quantification of Fom in asymptomatic melon seedlings and in their organic substrates. This technique allowed a sensitive and rapid detection of Fom in melon plant material and substrate as soon as $48 \mathrm{~h}$ after inoculation, compared with 5-6 days required by the culture-dependent techniques.

At present, however, no molecular tools are available to discriminate among Fom races and therefore further work will be necessary to develop new DNAbased technology for this purpose. In tomato, assays for xylem-secreted effector-transcripts of $F$. oxysporum f. sp. lycopersici were shown to correctly diagnose the fungal race (Lievens et al. 2009); such effectors, however, are yet to be discovered in $\mathrm{f}$. $\mathrm{sp}$. melonis. More recently, 75 cDNA fragments with differential expression between the races 1 and 1,2 were identified (Sestili et al. 2011). Such transcripts could provide markers for race identification, but this would require further studies.
Epidemiology and defense responses

Fom infects the root system, wherein it progresses through the epidermis, cortex and endodermal tissues and penetrates the xylem vessels through the pits. From this stage on, the fungus uses the xylem for upward movement and establishment throughout the plant (Bishop and Cooper 1983). Whilst in the xylem, the mycelium sporulates, and microconidia are carried upwards by the xylem stream. At vessel ends, conidia germinate and the secondary mycelium penetrates the next vessel.

Plant infection by $F$. oxysporum is therefore a complex process that comprises several stages of hostpathogen interaction: recognition of the host roots and adsorption; penetration of hyphae through the different root tissues; penetration and progression in the xylem; and adaptation to the internal plant environment. To be successful, the fungus must overcome different plant defense responses at each stage (Beckman and Roberts 1995; Di Pietro et al. 2003; Michielse and Rep 2009). During the final stage of infection, the fungus secretes lytic enzymes and toxins that lead to disease symptoms, including necrotic lesions, chlorosis and wilting. Melon resistance sources have been identified and genetically characterized, but the defense mechanisms that confer resistance remain elusive.

The interaction and dynamics of Fom race 1,2 colonization in a susceptible melon cultivar 'Ein Dor' versus resistant melon line BIZ has been documented using green fluorescent protein (GFP) as a marker (Zvirin et al. 2010). At 1-2 days post-inoculation, the fungus grew on the root epidermis and adhered to epidermal cell borders. By day 4, the mycelium crossed the cortex and endodermis through narrow pores in cell walls and reached xylem vessels, where it sporulated and produced secondary hyphae that grew upwards. Race 1,2 colonized the resistant plant's vascular system, but the incidence of seedling infection was lower than in susceptible 'Ein Dor', suggesting stronger defense responses in BIZ expressed at the pre-xylem stage of infection. Infection of the vascular system of BIZ was slower; at 11 days post-inoculation, race 1,2 only colonized the lower hypocotyl of BIZ, whilst the upper hypocotyls of 'Ein Dor' were already infected. Thus, Zvirin et al. (2010) established that resistant plants were not immune to the pathogen, but were able to quantitatively inhibit its progression 
by expressing an efficient defense response. They also demonstrated that transcript levels of phenylalanine ammonia lyase, chitinase and hydroperoxide lyase were induced to a greater extent in the resistant line.

Pretreatment of melon plants with dinitroaniline herbicides markedly increased their resistance to Fusarium wilt (Grinstein et al. 1976; Lotan-Pompan et al. 2007). Cohen et al. (1986) reported that the dinitroaniline herbicides trifluralin and dinitramine were the most effective for inducing resistance to Fom and suggested that reduction of wilt symptoms is associated with a reduction in ethylene production. In addition, higher glutathione levels following dinitroaniline treatment have been suggested to confer protection against Fom (Bolter et al. 1993).

Lotan-Pompan et al. (2007) identified, using suppression subtractive hybridization and cDNA-AFLP, seven genes whose expression is associated with resistance to Fom race 2 following trifluralin treatment. Furthermore, the authors demonstrated that expression of four stress-related and up-regulated genes was enhanced when the plants were subjected to salinity stress, suggesting that trifluralin induces a general stress response which protects the plant against Fusarium wilt.

\section{Resistance to Fom races 0,1 and 2}

\section{Sources of resistance to Fom races 0,1 and 2}

The Fom-1 gene, originally identified in melon cultivar 'Doublon', confers high-level of resistance to races 0 and 2, whereas the Fom-2 gene, originally identified in melon cultivar 'CM17187', confers high resistance to races 0 and 1 (Risser et al. 1976). To date, these genes have been extensively used in melon breeding and were already introduced to the majority of modern melon cultivars. However, it is desirable to have additional resistance sources available, because future adaptation of the pathogen could render specific resistance genes ineffective. Therefore, many studies searched for novel melon resistance sources to Fom (Zink 1983; Champaco et al. 1992; Pitrat et al. 1996; Álvarez et al. 2005). These studies revealed that, in the melon germplasm, resistance to Fom races 0,1 and 2 is more frequent than that to Fom race 1,2. Resistance traits were found in melon accessions belonging to different botanical varieties of $C$. melo $\mathrm{L}$. from different geographical origins, mostly areas of greater melon genetic diversity: the Iberian Peninsula, Far East and Middle East. Pitrat et al. (1996) screened an extensive collection of C. melo for resistance to Fom and found that $14.7 \%$ of the 353 accession tested were resistant to both races 0 and 2, and $13.8 \%$ were resistant to races 0 and 1 . In another study, Álvarez et al. (2005) found new resistance sources to Fom races 0,1 and 2 in a collection of 139 accessions from different geographical origins. Resistance to race 1 was less common than resistance to the other two races, since only four accessions showed race 1 resistance, whereas twelve were resistant to races 0 and 2.

\section{Genetics of resistance to Fom races 0,1 and 2}

The first genetic studies on Fom resistance were carried out by Messiaen et al. (1962). They described Fom resistance among French 'Cantaloupe Charentais' genotypes and selected open pollinated cultivars homogeneous for resistance, such as 'Doublon' and 'Védrantais'. This resistance was conditioned by a dominant gene called Fom-1 (Messiaen et al. 1962). Screening of the genetic resources led to the discovery of an independent dominant gene (Fom-2) in some accessions from the Far-East (CM 17187). This protection, however, was short-term, since it was overcome by novel Fom strains of race 1,2 (Risser et al. 1969).

Later, Zink and Gubler (1985) also described a dominant gene, Fom-3, as responsible for resistance to races 0 and 2 in melon line Perlita-FR. Fom- 3 is tightly linked to Fom- 1 and the two are suspected to be allelic. Risser (1987) affirmed that resistance in Perlita-FR is controlled by Fom-1 and the susceptible plants detected in the $F_{2}$ generation of the cross PerlitaFR $\times$ 'Doublon', used to test for allelism, could result from residual segregation occurring in the Perlita-FR parent used by Zink and Gubler (1985).

Recently, Oumouloud et al. (2010) reported a new recessive gene (fom-4) that confers, together with Fom-1, resistance to races 0 and 2 in the Tortuga melon line. Similar to the other $f$. oxysporum $F$. speciales, that have exclusively asexual reproduction and little potential for gene flow, Fom presents only a low risk to overcome major resistance genes (McDonald and Linde 2002). However, this situation may change because of the extensive commercial 
cultivation of melons carrying the resistance controlled by Fom-1 and Fom-2.

The use of different resistance genes such as fom- 4 could provide higher levels of resistance to Fom races 0 and 2; Tortuga may therefore constitute a new alternative source of resistance. In addition, resistance controlled by more than one gene might increase its durability (Khetarpal et al. 1998). Thus, better protection against race 2 could be achieved by combining two resistant genes, Fom-1 and fom-4. The combined use of the identified molecular markers linked to Fom1 gene (Oumouloud et al. 2009) and the ones linked to fom-4 we are developing at this moment (Oumouloud et al. 2012) would be very useful in marker assisted selection for introducing the two resistance genes into the melon varieties.

\section{Molecular markers linked to Fom-1 and Fom-2 genes}

The expression of MFW symptoms following artificial inoculation is affected by the virulence of the pathogen isolates (Namiki et al. 1998), the genetic background of the plant (Mas et al. 1981), and environmental factors such as temperature and light intensity (Cohen et al. 1996; Burger et al. 2003). Furthermore, some genetically susceptible plants may escape wilting following standard inoculation. Escapes as well as ambiguous symptom expression in controlled inoculation tests result in selection of false negatives that reduce selection progress for resistance to MFW. Molecular markers linked to genes conferring resistance to Fom have the potential to reduce or eliminate this problem, by ensuring that the chromosome segment that carries the resistance gene is selected and maintained even when the inoculation test is not very reliable, or strictly on the basis of the presence of the marker without disease testing.

Inoculation with non-pathogenic Fom races may confer cross-protection (Mas et al. 1981; Alabouvette and Couteaudier 1992; Freeman et al. 2001). Thus, inoculation with one pathogenic race could impede subsequent selection of the same plant for resistance to an additional race in a sequential testing series. It was found, in fact, that melon plants that survived inoculation with race 1 did not show any disease symptoms following subsequent inoculation with race 2 (ChikhRouhou et al. 2006). Hence, molecular markers enable simultaneous selection of genes for resistance to two or more Fom races.

\section{Development of molecular markers to the Fom-2 gene}

The bulk segregant analysis (BSA) strategy, described by Michelmore et al. (1991), was used to detect random amplified polymorphic DNA (RAPD) markers linked to Fom-2 (Wechter et al. 1995). These fingerprint markers have been transformed to more stable and convenient single-locus ones, such as cleaved amplified polymorphic sequences (CAPS; Zheng et al. 1999), or sequence characterized amplified region (SCAR; Zheng and Wolf 2000).

Combining the BSA strategy with amplified fragment length polymorphism (AFLP) methodology, Wang et al. (2000) found some AFLP markers linked to the Fom-2 locus, and converted them into codominant SCAR markers, designated 'AM' and 'FM' (Table 2). The usefulness of these SCAR markers for indirect selection of Fom-2 was confirmed across 24 melon accessions from diverse race 1 resistant and susceptible origins. These and other markers are regularly used by melon breeders and served as starting points for map-based cloning of the Fom-2 gene (see below).

\section{Cloning and characterization of Fom-2 gene}

The Fom-2 resistance gene was isolated by a mapbased cloning strategy using a population derived from the cross 'Vedrantais' $\times$ PI 161375 (Joobeur et al. 2004). Two additional populations have been derived from two $\mathrm{F}_{7}$ recombinant inbreed lines (RILs) segregating for Fom-2. A BAC contig was built from the MR-1 library (Luo et al. 2001), and the sequencing of two overlapping partial BAC clones identified three candidate genes. Research efforts concentrated on one of these genes because of its high similarity to resistance genes of the NBS-LRR class (Joobeur et al. 2004).

The putative Fom-2 gene is $3 \mathrm{~kb}$ long and contains an uninterrupted open reading frame predicted to encode a 1,073 amino acid polypeptide that includes the different features of non-TIR NBS-LRR proteins. In contrast to most members of this class, no evidence of CC structure was found in the $\mathrm{N}$ terminus of the Fom-2 protein. 
Table 2 Single-locus markers linked to Fom-2 gene

\begin{tabular}{|c|c|c|c|c|}
\hline Marker name & Marker type & Primers & Restriction enzyme & Reference \\
\hline $\mathrm{AM}$ & SCAR & $\begin{array}{l}5^{\prime} \text {-СTTCATCACTATTCGAGGATGAC-3' } \\
\text { 5'-CTTTCTGCACACCAACCAAAAGG-3' }^{\prime}\end{array}$ & - & Wang et al. (2000) \\
\hline FM & SCAR & 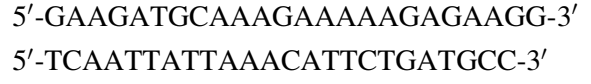 & - & Wang et al. (2000) \\
\hline CAPS2 & CAPS & $\begin{array}{l}\text { 5'-GGAAGTGAGGTGTTGAATT-3' } \\
\text { 5'-TACACATTGGTCCGTTAGAC-3' }\end{array}$ & EcoRI & Wang et al. (2011) \\
\hline CAPS3 & CAPS & $\begin{array}{l}\text { 5'-AGACGTAGCATTGCTTCTCTAG-3' } \\
\text { 5'-TGGCATCCTTCAGCACCTTC-3' }\end{array}$ & $X b a \mathrm{I}$ & Wang et al. (2011) \\
\hline Fom2-R 408 & SCAR & 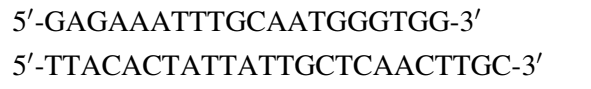 & - & Oumouloud et al. (2012) \\
\hline Fom2-S 342 & SCAR & $\begin{array}{l}5^{\prime} \text {-ATGAAAAGAAAAGATAACGACGA-3' } \\
\text { 5'-ATTGCTCTAAGTTGATCATATTCTG-3 }^{\prime}\end{array}$ & - & Oumouloud et al. (2012) \\
\hline
\end{tabular}

$S C A R$ sequence characterized amplified region, CAPS cleaved amplified polymorphic sequences

Additionally, Wang et al. (2011) described, using the Pfam software (http://pfam.sanger.ac.uk/), the detailed characteristics of this NBS-LRR protein. The protein harbours two significant Pfam-A match structures, an NB-ARC domain, and an LRR-1 domain. Another seven possible LRR-1s were observed at the $\mathrm{C}$ terminus of the Fom- 2 protein, that conformed with the consensus motif LxxLxxLxxLxx (N/C/T)x(x)L observed in cytoplasmic $R$-gene products (Jones and Jones 1997). The Fom-2 protein has also one Sfil C (spindle body associated protein C-terminus) domain and an EAF (ELL-associated factor) domain.

Joobeur et al. (2004) revealed that the amino acid sequences from three susceptible cultivars ('Védrantais', 'Ananas Yokneum' and 'Durango') were identical to each other; however, when compared with the amino acid sequences deduced from resistant genotypes (MR-1 and PI 161375), 25 amino acids out of 541 were different. The sequences of the LRR fragment from the two resistant lines were identical, except of three nucleotides. These differences resulted in the substitution of the amino acid residues $\mathrm{V}$ and $\mathrm{K}$ in MR-1 by M and E in PI 161375, respectively. So far, however, functional validation of the Fom-2 gene by transgenic complementation/silencing of resistance, or by TILLING, has not been reported. A preliminary study using transgenic roots of composite melon plants reported the expression of the Fom-2 promoter fragment along the vascular tissues (Normantovich et al. 2012). Using the same system to express the Fom-2 coding sequence in a Fom-susceptible background resulted in partial resistance in most, but not all experiments (Normantovich et al. 2012).

Recently, Oumouloud et al. (2012) reported the cloning and sequencing of a partial LRR fragment of Fom-2 from 11 melon resistant accessions from various geographic regions. They identified three alleles of Fom-2 and their results revealed that the structure of the Fom-2 LRR domain is highly conserved, since 8 of the 11 resistant genotypes showed similar alleles to the resistant one characterized in the PI 161375 line. Conversely, PI 124111 was the only line that presented the same resistant allele previously described in MR-1. This could be explained by the ancestral relations between the two lines (Monforte et al. 2003), as the MR-1 breeding line was derived from PI 124111 (Thomas 1986). Finally, accession Cum-355 carried a novel resistance allele that differs from both PI 161375 and MR-1.

The information generated from the Fom-2 LRR region sequences allowed systematic development of "Functional Markers" that were developed based on the nucleotide polymorphisms detected between the susceptible and resistant Fom-2 alleles (Wang et al. 2011; Oumouloud et al. 2012). Such markers were first documented in plants by Andersen and Lubberstedt (2003) and have been recently developed for several cloned $R$-genes. They are highly predictive of phenotype as they target the functional ("causal") polymorphism within a desired gene and overcome the problem of recombination between marker and trait. 
In this context, Wang et al. (2011) reported two CAPS markers, representing allele-specific markers based on SNP in the LRR region of Fom-2 (Table 2). In a parallel study, Oumouloud et al. (2012) developed two simple and efficient SCARs, Fom2-R 408 and Fom2-S 342 , that represent a pair of allele-specific markers (Table 2 ). The Fom $2-\mathrm{R}_{408}$ primers amplify a single band of 408 bp only in the resistant genotypes, whereas the Fom2-S 342 primers amplify a 342 bp band only in the susceptible ones. The two primer pairs can be combined in a multiplex PCR reaction, providing together a co-dominant marker. Such SCARs resulted in good identification of 27 resistant genotypes representing several melon horticultural types, enhancing the reliability and cost effectiveness of marker assisted selection for the Fom-2 gene.

\section{Molecular markers linked to Fom-1 gene}

The first molecular markers linked to this gene, were reported by Brotman et al. $(2002,2005)$ using two recombinant inbred line populations developed at "Institut National de la Recherche AgronomiqueFrance" (INRA). Based on BSA, Brotman et al. (2005) identified a RAPD marker that generated a 1,235-bp fragment linked to the Fom-1 gene in repulsion phase. This RAPD was converted to a CAPS marker designated as 62-CAPS (Table 3). This marker mapped at a distance of 0.7 and $6.3 \mathrm{cM}$ from Fom- 1 in the two populations, respectively. An additional marker, based on cloned resistance gene homologues (RGH), was designated NBS-1 (Brotman et al. 2005), transformed into a CAPS marker (Table 3), and mapped at $2.8 \mathrm{cM}$ from Fom-1.

Testing 62-CAPS and NBS1-CAPS in a set of 14 genotypes (seven resistant to Fom race 2 and seven susceptible) revealed a complex situation. The markers did not separate all the genotypes according to their resistance phenotype; instead, they seemed to group the accessions according to their horticultural or botanical groups, with group-specific marker haplotypes.

In a study that combined BSA and RAPD markers, Oumouloud et al. (2008) identified three molecular

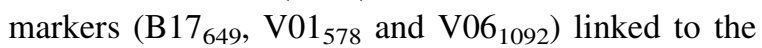
Fom-1 locus, using the $\mathrm{F}_{2}$ generation from the cross Charentais-Fom1 (Fom race 2 resistant) $\times$ TRG-1551 (susceptible). The polymorphic fragments were cloned, sequenced and converted to SCAR markers SB17 $645, \mathrm{SV01}_{574}$ and SV06 1092 respectively (Table 3).
The markers SB17 645 and SV01 574 amplified DNA fragments of 645 and $574 \mathrm{bp}$, respectively, in the resistant parent, while $\mathrm{SVO6}_{1092}$ amplified a 1,092 bp fragment only in the susceptible parent. Markers SB $17_{645}$ and SV01 $1_{574}$ were linked in coupling phase to Foml, at 3.5 and $4 \mathrm{cM}$, respectively, whereas SV06 $_{1092}$ was more distant $(15.1 \mathrm{cM})$. The application of these three markers across 24 melon Fom race 2 resistant and susceptible accessions from diverse origins revealed different marker haplotypes and supported multiple, independent origins of this resistance trait. Nevertheless, since the markers are not very tightly linked to the gene, recombination could also explain cases of incorrect genotyping.

In a different study, four AFLP markers linked to Fom-1 (GTC/ATG-260, TCG/GGT-400, TAG/GCC470 and GTG/ACC) have been identified using the BSA approach (Tezuka et al. 2009). These markers were mapped in $125 \mathrm{~F}_{2}$ individuals derived from the cross between line MR-1 (Fom race 2 resistant), and the susceptible Japanese line P11. Markers GTC/ ATG-260 and TCG/GGT-400 were linked in coupling phase to $F o m-1$ at 0.5 and, $4.9 \mathrm{cM}$ respectively, whereas TAG/GCC-470 was linked in repulsion to the resistant allele at $0 \mathrm{cM}$. The fourth marker, GTG/ ACC, was considered co-dominant and mapped at $10.3 \mathrm{cM}$ from Fom-1. TAG/GCC-470 was converted to a SCAR designated S-TAG/GCC-470 that amplified a single fragment ( $347 \mathrm{bp}$ ) only from P11 and the susceptible bulks (Table 3). Sequencing of regions flanking TCG/GGT-400 allowed the development of two CAPS markers, C-TCG/GGT-400 and CAPS2 (Table 3).

The usefulness of these DNA markers in determining the Fom- 1 genotype was tested with several fixed lines and commercial $F_{1}$ melon hybrids. The results, like the ones discussed above, differed among horticultural types. S-TAG/GCC-470, GTC/ATG-260 and C-TCG/GGT-400 corresponded well to the Fom-1 genotype in var. reticulatus and cantalupensis but not in vars. chinensis, conomon and makuwa.

Tezuka et al. (2011) developed a SCAR marker (SMRGH9) and three CAPS markers (CAPS3, C-MRGH12 and C-MRGH13) based on the published BAC 31016 sequence (Van Leeuwen et al. 2005), which contains a cluster of melon RGH and maps around the Fom-1 locus (Table 3).

These markers were mapped using the same $F_{2}$ population (Tezuka et al. 2009), as well as a collection 
Table 3 DNA markers linked to Fom-1 gene

\begin{tabular}{|c|c|c|c|c|}
\hline Marker name & $\begin{array}{l}\text { Marker } \\
\text { type }\end{array}$ & Primers & $\begin{array}{l}\text { Restriction } \\
\text { enzyme }\end{array}$ & Reference \\
\hline NBS1-CAPS & CAPS & 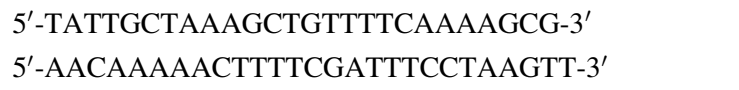 & Alw26I & Brotman et al. (2005) \\
\hline 62-CAPS & CAPS & $\begin{array}{l}\text { 5'-GGAGAAGATGCTAGAGCCATTC-3' } \\
\text { 5'-AATCGGGCATCCTGTTTTGG-3' }\end{array}$ & NcoI & Brotman et al. (2005) \\
\hline SB17 645 & SCAR & $\begin{array}{l}\text { 5'-AGGGAACGAGTTGAGAGAGCTAGA-3' } \\
\text { 5'-CGAGGATTCTTAACTAGCATGGA-3' }\end{array}$ & - & Oumouloud et al. (2008) \\
\hline SV01 574 & SCAR & $\begin{array}{l}\text { 5'-TGACGCATGGAATGAAATAAA-3' } \\
5^{\prime} \text {-GCATGGCCAAGGTCGAATA-3' }\end{array}$ & - & Oumouloud et al. (2008) \\
\hline SV06 $_{1092}$ & SCAR & $\begin{array}{l}\text { 5'-ACGCCCAGGTATCATATACACC-3' } \\
\text { 5'-ACGCCCAGGTTACGAAGTCA-3' }\end{array}$ & - & Oumouloud et al. (2008) \\
\hline CAPS2 & CAPS & $\begin{array}{l}\text { 5'-CAATTTTGGTTTCTTTGGATGG-3' } \\
5^{\prime} \text {-TTTCGAGGTTAGAGGTTTGTCA-3' }\end{array}$ & TaqI & Tezuka et al. (2009) \\
\hline S-TAG/GCC-470 & SCAR & $\begin{array}{l}\text { 5'-GAATTCTAGACTGAGCTTATAAACC-3' } \\
5^{\prime} \text {-TTAAGCCTAAAAGGGAATGGCCCCC-3' }\end{array}$ & - & Tezuka et al. (2009) \\
\hline C-TCG/GGT-400 & CAPS & $\begin{array}{l}5^{\prime} \text {-TTCAAAATCAAAGGAAATGCAA-3' } \\
5^{\prime} \text {-GGACCCAAACTTACCCTACACTT-3' }\end{array}$ & EcoRI & Tezuka et al. (2009) \\
\hline 618-CAPS & CAPS & $\begin{array}{l}\text { 5'-CTGGAGCCCAAATGAACAAAC-3' } \\
\text { 5'-GCTGGAGCATTCTAGTAATGAAA-3' }^{\prime}\end{array}$ & $T f i \mathrm{I}$ & Oumouloud et al. (2010) \\
\hline S-MRGH9 & STS & $\begin{array}{l}5^{\prime} \text {-GGTTGGCGATCTCACTGGAG-3' } \\
5^{\prime} \text {-TTTACCAATTCCGCCCATCC-3' }\end{array}$ & - & Tezuka et al. (2011) \\
\hline CAPS3 & CAPS & $\begin{array}{l}5^{\prime} \text {-GTTGGAGATGTTCCCTTGGA-3' } \\
5^{\prime} \text {-ACCTGGCAACTTTGGTTTTG-3' }\end{array}$ & HaeIII & Tezuka et al. (2011) \\
\hline C-MRGH12 & CAPS & $\begin{array}{l}5^{\prime} \text {-CGTCGGGTATGTCTCCATCT-3' } \\
5^{\prime} \text {-TGATGCTGCTGATGGACTTC-3' }\end{array}$ & $X m n \mathrm{I}$ & Tezuka et al. (2011) \\
\hline C-MRGH13 & CAPS & $\begin{array}{l}5^{\prime} \text {-CCACCCATTCCCCATATTCC-3' } \\
5^{\prime} \text {-TGAGGAAGCAGGAGGGGAAC-3' }\end{array}$ & $\operatorname{Taq} \mathrm{I}$ & Tezuka et al. (2011) \\
\hline 160P4-T7 & CAPS & $\begin{array}{l}\text { 5'-GGTTAGATGTTGAATTAATGG-3' } \\
5^{\prime} \text {-TCTCGAGTGTTTAGTGAGTTGG-3' }\end{array}$ & TaiI & Brotman et al. (2012) \\
\hline RG10-1 & CAPS & $\begin{array}{l}5^{\prime} \text {-CCTGTACTCTTGAAATCGAACAA-3' } \\
5^{\prime} \text {-TTGTGGAAGACTAAAAGAGGTTCA-3' }\end{array}$ & $D d e \mathrm{I}$ & Brotman et al. (2012) \\
\hline RG-A & CAPS & $\begin{array}{l}\text { 5'-GCCATGCTTCTTCTCTGAGC-3' } \\
5^{\prime} \text {-CCAATTCTCTCAAACACCACTTT-3' }\end{array}$ & SwaI & Brotman et al. (2012) \\
\hline RG9-2 & CAPS & $\begin{array}{l}\text { 5'-TCTGTTGGAAGCGTTTGATG-3' } \\
\text { 5'-TTGGCTCCAAATCATTTAGCTT-3' }^{\prime}\end{array}$ & $D d e \mathrm{I}$ & Brotman et al. (2012) \\
\hline RG-G & CAPS & $\begin{array}{l}5^{\prime} \text {-AGCGTGTGGTATGCAGACAG-3' } \\
5^{\prime} \text {-CAAGAATCCAACACGGGAGT-3' }\end{array}$ & BsuRI & Brotman et al. (2012) \\
\hline 160P4-SP6 & CAPS & $\begin{array}{l}\text { 5'-GCATGTTAGGGATTGTACATTC-3' } \\
\text { 5'-TTGTTGGCTTTTAGTTTTTCTGTCCATTTCGTTC-3' }^{\prime}\end{array}$ & $\operatorname{Taq} \mathrm{I}$ & Brotman et al. (2012) \\
\hline
\end{tabular}

$S C A R$ sequence characterized amplified region, CAPS cleaved amplified polymorphic sequences

of 104 recombinant inbred lines derived from the cross MR-1 $\times$ P11. A set of 70 melon genotypes, that included 43 fixed lines and 27 commercial $\mathrm{F}_{1}$ hybrids were used to test the usefulness of the above markers. According to the authors, C-TCG/GGT-400 seems suitable for Fom-1 genotyping in var. cantalupensis, 
while CAPS2, NBS1-CAPS, C-MRGH12 and 62-CAPS are suitable, with few exceptions, for genotyping accessions from vars. chinensis, conomon and makuwa.

The variety-dependent usefulness of DNA markers might indicate that there is no linkage disequilibrium between Fom-1 and the markers, and crossing over has occurred in some cultivars and lines. Another explanation is that the $R$ gene cluster around the Fom- 1 locus is very polymorphic; the four alleles detected by C-MRGH13 (Tezuka et al. 2011) could also reflect such polymorphisms.

\section{Characterization of Fom-1 gene}

The Fom- 1 gene was isolated by a map-based cloning strategy (Brotman et al. 2012). A backcross ('Védrantais' $\times$ PI 414723$) \times$ PI 414723 population of 1190 individuals was screened for recombination events within the interval delimited by markers NBS1 and 62-CAPS flanking the Fom-1 locus. In parallel, all $\mathrm{BC}_{1} \mathrm{~S}_{1}$ families were inoculated with Fom race 2 . The region was sequenced using libraries, and progenies displaying recombination events were genotyped by additional BAC-based markers. The results indicated that Fom- 1 was separated by a single recombinant from marker RG9-2 (Table 3), residing in exon 2 of the NB-LRR homologue, RGH9. On its other side, Fom- 1 was flanked by marker RG-G (Table 3 ) that maps between RGH8 and RGH9. This identified RGH9 as the Fom-1 gene. The sequence analysis revealed that this gene belongs to the TIR-NB-LRR type. Further studies will be required to elucidate the molecular polymorphism between resistant and susceptible alleles and provide functional validation of the Fom- 1 gene action.

\section{Resistance to Fom race 1,2}

\section{Sources of resistance to Fom race 1,2}

As previously stated, many resources of high resistance to race 0,1 , and 2 have been reported, and incorporated into commercial melon cultivars; nevertheless, no gene that confers complete resistance to either race $1,2 \mathrm{w}$ or $1,2 \mathrm{y}$ has been reported, although partial resistance has been found.
The first report of melon resistance to Fom race 1,2 was recorded by Risser and Rode (1973) from accessions Ogon-9 and Piboule. Later, Pitrat et al. (1996) established that sources of resistance to race 1,2 are restricted to a few Far-Eastern accessions belonging to $C$. melo subsp. agrestis. When screening melon accessions from different geographical origins for resistance to race 1,2 , they found that only $3 \%$ of the 271 accessions tested showed some resistance, all of them from the Far East. The resistance to race 1,2 described in accessions Ogon-9 and Piboule allowed breeding of partially resistant lines, such as Isabelle (Risser and Rode 1973), two doubled-haploid lines, Nad-1 and Nad-2 (Ficcadenti et al. 2002), and some commercial hybrids.

Additionally, Hirai et al. (2002) selected two melon rootstocks cultivars 'Dodai No. 2' and 'Dodai No.1' that showed partial resistant to the race 1,2y. Also, Herman and Perl-Treves (2007) reported a near complete resistance to race 1,2 of Fom in the breeding line BIZ, and showed that BIZ definitely had a higher level of resistance than Isabelle. An $\mathrm{F}_{1}$ hybrid, 'Adir', derived by crossing BIZ with a non-resistant counterpart, displayed good field resistance to race 1,2. 'Adir' also was used as a rootstock for the susceptible melon cultivar 'Ophir', and provided good protection against MFW (Horev 2002).

High resistance levels to race 1,2 have been described in three Japanese melon accessions (Kogane Nashi Makuwa, C-211, and C-40), and useful levels in one Russian (C-160) and two Spanish (C-300 and Mollerusa-7) accessions (Oumouloud et al. 2009). Chikh-Rouhou et al. (2010) screened 110 melon accessions from diverse origins for resistance to race 1,2 and reported partial resistance to this race within a Portuguese accession BG-5384 belonging to var. cantalupensis. Matsumoto et al. (2011) found highlevel of resistance to race $1,2 \mathrm{y}$ in 34 of 76 accessions from 7 of 11 wild Cucumis spp. Nevertheless, this highlevel resistance to race $1,2 \mathrm{y}$ could not be introduced into melon cultivars, because of strong reproductive barriers between melon and the wild Cucumis spp.

Genetics of resistance to Fom races 1,2

Resistance to Fom race 1,2 is complex and appears to be under polygenic control. Perchepied and Pitrat (2004) reported the mode of inheritance of resistance to Fom race 1,2 in the partially resistant line Isabelle 
using a RIL population derived from an $\mathrm{F}_{1}$ hybrid between Isabelle, and the susceptible cultivar, 'Védrantais'. The authors confirmed that resistance to race 1,2 in Isabelle is under polygenic control, and established that the heritability of resistance was high (0.72-0.96), and the minimum number of effective factors controlling the resistance ranged between 4 and 14. They also showed that some RILs were significantly more susceptible than 'Védrantais'; this result may indicate transgressive segregation, which implies that the susceptible parent 'Védrantais', may also have alleles for resistance.

Herman and Perl-Treves (2007) studied the nature of Fom race 1,2 resistance in the $\mathrm{F}_{2}$ and backcross generations from the cross between BIZ and PI 414723. Segregation of the resistance response in these populations supported a model in which two complementary, recessive genes, designated fom- $1,2 a$ and fom$1,2 b$, are required to obtain full resistance. Recently, Chikh-Rouhou et al. (2011) determined the mode of inheritance of resistance to Fom race 1,2 in lines BG5384, Shiro Uri Okayama, Kogane Nashi Makuwa and $\mathrm{C}-211$. The $\mathrm{F}_{1}, \mathrm{~F}_{2}$, and reciprocal backcross generations from the crosses between the above four resistant accessions and 'Piel de Sapo', a Fom race 1,2 susceptible melon, were analyzed by inoculation with isolates belonging to the $1,2 \mathrm{y}$ and $1,2 \mathrm{w}$ pathotypes. The distribution of the area under the disease progress curve (AUDPC) values in the $\mathrm{F}_{2}$ and $\mathrm{BC}$ generations after inoculation with both pathotypes of race 1,2 of Fom was continuous, suggesting quantitative inheritance of resistance. Broad-sense heritabilities ranged from 0.48 to 0.59 . Such relatively moderate values could be explained by the existence of several factors involved in the resistance and the epistatic effects detected in this study. Additive, dominance, and epistatic effects were significant in all crosses, which indicates that the resistance is under complex genetic control in the four accessions. Additive effects were always positive and significant, regardless of the pathotype, indicating that it should be possible to increase resistance levels by accumulating resistance genes.

QTL mapping

Following the above reported inheritance study, Perchepied et al. (2005) performed QTL-analysis of the resistance to Fom 1,2 in breeding line Isabelle using the same 120 RIL population described above.
They identified a total of nine QTL located on five linkage groups, most of them at linkage group ends, together explaining between 41.9 and $66.4 \%$ of the total variation. Most of these QTL appear to be recessive. The resistant alleles of seven QTL originated from the partially resistant parent Isabelle, whereas resistance alleles of two QTL came from the susceptible parent, 'Védrantais'. This agreed with the observed significant transgression towards susceptibility (Perchepied and Pitrat 2004).

Among the QTL, fomIII.1 and fomVI.1 were specific for the $\mathrm{Y}$ pathotype, while fomV.2 and fomXII.1 were only identified following inoculation with pathotype $\mathrm{W}$ strains. On the other hand, five QTL, fomIII.2, fomIII.3, fomV.1, fomXI.1, and fomXII.1, were effective against both pathotypes $\mathrm{Y}$ and $\mathrm{W}$. These results suggested that partial resistance to Fom race 1,2 is governed by pathotype-shared loci, as well as by pathotype-specific loci.

QTL fomV.2 co-localized with the resistance genes Vat, which confers resistance to aphid colonization and virus transmission, and $P m-w$ for powdery mildew resistance, within a cluster of resistance gene homologs (RGH; Brotman et al. 2002; Garcia-Mas et al. 2001). QTL fomXI.1 co-localized with the resistance gene Fom-2 (marker AM), which confers resistance to Fom races 0 and 1, and with the RGH sequence NBS3 (Brotman et al. 2002). The Fom-2 gene itself has not been reported to contribute to race 1,2 resistance, therefore the loci implicated in resistance to Fom race 1,2 and races 0 and 1 may be different, but tightly linked. The presence of both quantitative and qualitative resistance genes in the same genomic regions suggests that QTL may correspond to allelic variation of qualitative resistance genes with intermediate phenotypes (Robertson 1989).

More recently, analysis of the melon genome sequence revealed that the resistance genes were organized in clusters. In particular, 79 R-genes were located within 19 genomic clusters, 16 with genes belonging to the same family. In the genomic interval of less than $135 \mathrm{~kb}, 7$ TIR-NBS-LRR genes were clustered and located at the region harbouring the Fom-1 resistance gene (Garcia-Mas et al. 2012).

Herman et al. (2008) reported a preliminary QTL analysis for resistance to Fom race 1,2 in the breeding line BIZ using a set of $154 \mathrm{~F}_{3}$ families derived from the cross between this line and PI 414723. A major recessive QTL for resistance to Fom race 1,2 
originated from Biz was detected in linkage group 2 (Gonzalo et al. 2005) that doesn't harbour the QTL described by Perchepied et al. (2005). The authors hypothesized that BIZ and Isabelle might carry different loci for resistance and not just different alleles in similar loci.

\section{Conclusion}

Two dominant resistance genes, Fom-1 and Fom-2, control resistance to races 0 and 2 , and 0 and 1 , respectively. Many sources of resistance to these races have been found in several accessions belonging to different melon botanical varieties and the resistance was introduced to many melon commercial cultivars. Many molecular markers, linked to Fom-1 and Fom-2, potentially useful for marker-assisted selection have been identified. The Fom-2 gene was cloned and characterized, and SNP-based functional markers associated with resistance to race 1 were developed. These markers are expected to enhance the reliability and cost effectiveness of marker-assisted selection for the Fom-2 gene in melon.

Regarding the Fom-1 gene, several molecular markers linked to this gene have been reported; nevertheless, their usefulness was variety-dependent. The recent cloning of this gene, which encodes a TIRNB-LRR protein, now paves the way to its full molecular characterization.

The new recessive gene fom- 4 , reported in Tortuga, should be studied in depth since it could prevent future breaking of resistance. Development of markers associated with fom-4 is under way, and will be used for pyramiding genes to further increase the durability of resistance to race 2 .

Sources of high resistance to Fom race 1,2 predominantly come from Far Eastern accessions belonging to C. melo subsp. agrestis such as Ogon-9 or Kogani Nashi Makuwa. These accessions are organoleptically different from the cultivated melons. Resistance to race 1,2 is complex, and appears to be controlled by multiple recessive genes, except in breeding line BIZ, where it was reported to be controlled by two recessive genes. To date, QTL associated with resistance to race 1,2 have been reported only in the lines Isabelle and BIZ. The availability of the melon genome sequence (GarciaMas et al. 2012) and the use of newer technologies such as DNA microarrays will accelerate genome mapping and tagging of new QTL associated with resistance to race 1,2. These QTLs could be used to transfer the resistance into high yielding melon genotypes and combine different QTL with major resistance genes to the other races.

Open Access This article is distributed under the terms of the Creative Commons Attribution License which permits any use, distribution, and reproduction in any medium, provided the original author(s) and the source are credited.

\section{References}

Alabouvette C, Couteaudier Y (1992) Biological control of Fusarium wilts with nonpathogenic Fusaria. In: Tjamos ES (ed) Biological control of plant diseases. Plenum Press, New York, pp 415-426

Álvarez JM, González-Torres R, Mallor C, Gómez-Guillamón ML (2005) Potential sources of resistance to Fusarium wilt and powdery mildew in melons. HortScience 40:16571660

Andersen JR, Lubberstedt T (2003) Functional markers in plants. Trends Plant Sci 8:554-560

Appel DJ, Gordon TR (1995) Intra-specific variation within populations of Fusarium oxysporum based on RFLP analysis of the intergenic spacer (IGS) region of the rDNA. Exp Mycol 19:120-128

Armstrong GM, Armstrong JK (1978) Formae speciales and races of Fusarium oxysporum causing wilts of the Cucurbitaceae. Phytopathology 68:19-28

Baayen RP (2000) Diagnosis and detection of host-specific forms of Fusarium oxysporum. EPPO Bull 30:489-491

Beckman CH, Roberts EM (1995) On the nature and genetic basis for resistance and tolerance to wilt diseases of plants. Adv Bot Res 21:35-77

Bishop CD, Cooper RM (1983) An ultra-structural study of vascular colonization in three vascular wilt diseases.1. Colonizationof susceptible cultivars. Physiol Plant Pathol 23:323-343

Bolter C, Brammall RA, Cohen R, Lazarovits G (1993) Glutathione alterations in melon and tomato roots following treatment with chemicals which induce disease resistance to Fusarium wilt. Physiol Mol Plant Pathol 42:321-336

Booth C (1971) The genus Fusarium. Coomonwealth Mycological Institute, Kew, p 237

Bouhot D (1981) Some aspects of the pathogenic potential in formae specials and races of Fusarium oxysporum on $\mathrm{Cu}$ curbitaceae. In: Nelson PE, Toussoun TA, Cook RJ (eds) Fusarium: disease, biology, and taxonomy. Pennsylvania State University Press, University Park, pp 318-326

Brimner T, Boland G (2003) A review of the non-target effects of fungi used to biologically control plant diseases. Agric Ecosyst Environ 100:3-16

Brotman Y, Silberstein L, Kovalski I, Périn C, Dogimont C, Pitrat M, Klingler J, Thompson GA, Perl-Treves R (2002) Resistance genes homologues in melon are linked to 
genetic loci conferring disease and pest resistance. Theor Appl Genet 104:1055-1063

Brotman Y, Kovalski I, Dogimont C, Pitrat M, Portnoy V, PerlTreves R (2005) Molecular markers linked to papaya ring spot virus resistance and Fusarium race 2 resistance in melon. Theor Appl Genet 110:337-345

Brotman Y, Normantovich M, Goldenberg Z, Zvirin Z, Kovalski I, Stovbun N, Donniger T, Bolger AM, Troadec C, Bendahmane A, Cohen R, Katzir N, Pitrat M, Dogimont C, Perl-Treves R (2012) Dual resistance of melon to Fusarium oxysporum races 0 and 2 and to Papaya ring-spot virus is controlled by a pair of head-to-head oriented NB-LRR genes of unusual architecture. Mol Plant 6(1):235-238

Burger Y, Katzir N, Tzuri G, Portnoy V, Saar U, Shriber S, PerlTreves R, Cohen R (2003) Variation in the response of melon genotypes to Fusarium oxysporum f. sp. melonis race 1 determined by inoculation tests and molecular markers. Plant Pathol 52:204-211

Cebolla B, Busto J, Ferrer A, Miguel A, Maroto JV (2000) Methyl bromide alternatives on horticultural crops. Acta Hortic 532:237-242

Champaco ER, Martyn RD, Miller ME (1992) Evaluation of muskmelon germplasm for resistance to Fusarium wilt. Subtrop Plant Sci 45:39-42

Chikh-Rouhou H, Alvarez M, González-Torres R (2006) Induced resistance in melon plants against Fusarium oxysporum $\mathrm{f}$. sp. melonis caused by a nonpathogenic isolate of the same formae specialis. Commun Agric Appl Biol Sci 71:985-991

Chikh-Rouhou H, Oumouloud A, González-Torres R, Álvarez JM (2010) Screening and morphological characterization of melons for resistance to Fusarium oxysporum f. sp. melonis race 1,2. HortScience 45:1021-1025

Chikh-Rouhou H, González-Torres R, Oumouloud A, Álvarez JM (2011) Inheritance of race 1,2 Fusarium wilt resistance in four melon cultivars. Euphytica 82:177-186

Chupp C (1930) Fusarium wilt of muskmelon. Plant Dis Rep $14: 160$

Cohen R, Riov J, Lisker N, Katan J (1986) Involvement of ethylene in herbicide-induced resistance to Fusarium oxysporum f. sp. melonis. Phytopathology 76:1281-1285

Cohen R, Blaier B, Schaffer AA, Katan J (1996) Effect of acetochlor treatment of Fusarium wilt and sugar content in melon seedlings. Eur J Plant Pathol 102:45-50

Cohen R, Horev C, Burger Y, Shraiber S, Hershenhorn J, Katan J, Edelstein M (2002) Horticultural and pathological aspects of Fusarium wilt management using grafted melons. HortScience 37:1069-1073

Crino P, Lo Bianco C, Rouphael Y, Colla G, Saccardo F, Paratore A (2007) Evaluation of rootstock resistance to Fusarium wilt and gummy stem blight and effect on yield and quality of a grafted 'Inodorus' melon. HortScience 42:521-525

Di Pietro A, Madrid MP, Caracuel Z, Delgado-Jarana J, Roncero MIG (2003) Fusarium oxysporum: exploring the molecular arsenal of a vascular wilt fungus. Mol Plant Pathol 4:315-325

Ficcadenti N, Sestili S, Annibali S, Campanelli G, Belisario A, Maccaroni M, Corazza L (2002) Resistance to Fusarium oxysporum f. sp. melonis race 1,2 in muskmelon lines Nad1 and Nad-2. Plant Dis 86:897-900
Freeman S, Zveibil A, Vintal H, Maimon M (2001) Isolation of nonpathogenic mutants of Fusarium oxysporum f. sp. melonis for biocontrol of Fusarium wilt in cucurbits. Phytopathology 92:164-168

Garcia-Mas J, Leeuwen HV, Monfort A, Carmen de Vicente M, Puigdomenech P, Arus P (2001) Cloning and mapping of resistance gene homologues in melon. Plant Sci 161:165-172

Garcia-Mas J et al (2012) The genome of melon (Cucumis melo L.). Proc Natl Acad Sci USA 109:11872-11877

Glass NL, Jacobson DJ, Shiu PK (2000) The genetics of hyphal fusion and vegetative incompatibility in filamentous ascomycete fungi. Annu Rev Genet 34:165-186

Gonzalo MJ, Oliver M, Garcia-Mas J, Monfort A, DolcetSanjuan R, Katzir N, Arus P, Monforte A (2005) Simplesequence repeat markers used in merging linkage maps of melon (Cucumis melo L.). Theor Appl Genet 110:802-811

Gordon TR, Martyn RD (1997) The evolutionary biology of Fusarium oxysporum. Ann Rev Phytopathol 35:11-128

Gordon TR, Okamoto D (1992) Variation in mitochondrial DNA among vegetatively compatible isolates of Fusarium oxysporum. Exp Mycol 16:245-250

Gordon TR, Okamoto D, Jacobson DJ (1989) Colonization of muskmelon and non-host crops by Fusarium oxysporum $\mathrm{f}$. sp. melonis and other species of Fusarium. Phytopathology 79:1095-1100

Grinstein A, Katan J, Eshel Y (1976) Effect of dinitroaniline herbicides on plant resistance to soilborne pathogens. Phytopathology 66:517-522

Guadet J, Julien J, Lafay JF, Brygoo Y (1989) Phylogeny of some Fusarium species, as determined by large-subunit rRNA sequence comparison. Mol Biol Evol 6:227-242

Gullino ML, Camponogara A, Gasparrini G, Rizzo V, Clini C, Garibaldi A (2003) Replacing methyl bromide for soil desinfestation. Plant Dis 87:1012-1021

Gwynne BJ, Gordon TR, Davis RM (1997) A new race of Fusarium oxysporum f. sp. melonis causing Fusarium wilt of muskmelon in the central valley of California. Plant Dis 81:1095

Herman R, Perl-Treves R (2007) Characterization and inheritance of a new source of resistance to Fusarium oxysporum f. sp. melonis Race 1,2 in Cucumis melo. Plant Dis 91(9):1180-1186

Herman R, Zvirin Z, Kovalski I, Freeman S, Denisov Y, Zuri G, Katzir N, Perl-Treves R (2008) Characterization of Fusarium race 1,2 resistance in melon and mapping of a major QTL for this trait near a fruit netting locus. Proceedings of the IXth EUCARPIA meeting on genetics and breeding of Cucurbitaceae, Avignon, France, pp 149-156

Hirai G, Nakazumi H, Yagi R, Nakano M (2002) Fusarium Wilt (race 1,2y) resistant melon (Cucumis melo) rootstock cultivars 'Dodai No.1' and 'Dodai No.2'. Acta Hortic 588: $155-160$

Horev C (2002) Grafted melons for controlling Fusarium wilt caused by Fusarium oxysporum f. sp. melonis: horticultural and pathological aspects. M.Sc. thesis. Hebrew University of Jerusalem

Jacobson DJ, Gordon TR (1990a) Further investigations of vegetative compatibility within Fusarium oxysporum $\mathrm{f}$. sp. melonis. Can J Bot 68:1245-1248 
Jacobson DJ, Gordon TR (1990b) Variability of mitochondrial DNA as an indicator of relationships between populations of Fusarium oxysporum f. sp. melonis. Mycol Res 94:734-744

Jones DA, Jones JDG (1997) The role of leucine-rich repeat proteins in plant defences. Adv Bot Res Inc Adv Plant Pathol 24:89-167

Joobeur T, King JJ, Nolin SJ, Thomas CE, Dean RA (2004) The Fusarium wilt resistance locus Fom-2 of melon contains a single resistance gene with complex features. Plant J 39:283-297

Khetarpal RK, Maisonneuve B, Maury Y, Chalhoub B, Dinant S, Lecoq H, Varma A (1998) Breeding for resistance to plant viruses. In: Hadidi A, Khetarpal RK, Koganezawa H (eds) Plant virus disease control. The American Phytopathological Society, St. Paul, pp 14-32

King SR, Davis AR, Liu W, Levi A (2008) Grafting for disease resistance. HortScience 43:1673-1676

Komada H (1975) Development of a selective medium for quantitative isolation of Fusarium oxysporum from natural soil. Rev Plant Prot Res 8:114-125

Leach JG, Currence TM (1938) Fusarium wilt of muskmelon in Minnesota. Minn Agric Exp Stn Tech Bull 129:32

Lievens B, Houterman PM, Rep M (2009) Effector gene screening allows unambiguous identification of Fusarium oxysporum f. sp. lycopersici races and discrimination from other Formae speciales. FEMS Microbiol Lett 300:201215

López-Mondéjar R, Beaulieu R, Ros M, Pascual JA (2012) SCAR-based real-time TaqMan PCR for early detection of Fusarium oxysporum in melon seedlings under greenhouse nursery conditions. Crop Prot 33:1-6

Lotan-Pompan M, Cohen R, Yarden O, Portnoy V, Burger Y, Katzir N (2007) Trifluralin herbicide-induced resistance of melon to Fusarium wilt involves expression of stress- and defence-related genes. Mol Plant Pathol 8:9-22

Luo M, Wang YH, Frisch D, Joobeur T, Wing R, Dean RA (2001) Melon BAC library construction using improved methods and identification of clones linked to the locus conferring resistance to melon Fusarium wilt (Fom-2). Genome 44:154-162

Mas P, Molot PM, Risser G (1981) Fusarium wilt of muskmelon. In: Nelson PE, Toussen TA, Cook RJ (eds) Fusarium: disease, biology and taxonomy. Pennsylvania State University Press, University Park, pp 169-177

Matsumoto Y, Ogawara T, Miyagi M, Watanabe N, Kuboyama $\mathrm{T}$ (2011) Response of Wild Cucumis species to inoculation with Fusarium oxysporum f. sp. melonis race 1,2y. J Jpn Soc Hortic Sci 80:414-419

McDonald BA, Linde C (2002) Pathogen population genetics, evolutionary potential and durable resistance. Annu Rev Phytopathol 40:349-379

Messiaen CM, Risser G, Pecaut P (1962) Etude des plantes résistantes au Fusarium oxysporum f. sp. melonis dans la variété de melon Cantaloup Charentais. Ann Amélior Plantes 12:157-164

Michelmore RW, Paran I, Kesseli RV (1991) Identification of markers linked to disease-resistance genes by bulked segregant analysis: a rapid method to detect markers in specific genomic regions by using segregating populations. Proc Natl Acad Sci USA 88:9828-9832
Michielse CB, Rep M (2009) Pathogen profile update: Fusarium oxysporum. Mol Plant Pathol 10:311-324

Mohammadi MM, Aminipour M, Banihashemi Z (2004) Isozyme analysis and soluble mycelial protein pattern in Iranian isolates of several Formae speciales of Fusarium oxysporum. J Phytopathol 152:267-276

Monforte AJ, Garcia-Mas J, Arús P (2003) Genetic variability in melon based on microsatellite variation. Plant Breed 122:153-157

Namiki F, Shiomi T, Nishi K, Kayamura T, Tsuge T (1998) Pathogenic and genetic variation in the Japanese strains of Fusarium oxysporum f. sp. melonis. Phytopathology 88:804-810

Normantovich M, Yogev O, Taylor CG, Perl-Treves R (2012) Study of the Fom-2 resistance gene using composite melon plants. In: Proceedings of the X Eucarpia meeting on the Cucurbitaceae, Antalia, Turkey, October 15-18th, 2012, pp 240-246

Oumouloud A, Arnedo-Andres MS, Gonzalez-Torres R, Álvarez JM (2008) Development of molecular markers linked to the Fom-1 locus for resistance to Fusarium race 2 in melon. Euphytica 164:347-356

Oumouloud A, Arnedo-Andres MS, González-Torres R, Álvarez JM (2009) Morphological and molecular characterization of melon accessions resistant to Fusarium wilts. Euphytica 169:69-79

Oumouloud A, Arnedo-Andrés MS, González-Torres R, Álvarez JM (2010) Inheritance of resistance to Fusarium oxysporum f. sp. melonis races 0 and 2 in melon accession Tortuga. Euphytica 176:183-189

Oumouloud A, Mokhtari M, Chikh-Rouhou H, Arnedo-Andrés MS, González-Torres R, Álvarez JM (2012) Characterization of the Fusarium wilt resistance Fom-2 gene in melon. Mol Breed 30:325-334

Perchepied L, Pitrat M (2004) Polygenic inheritance of partial resistance to Fusarium oxysporum $\mathrm{f}$. sp. melonis race 1,2 in melon. Phytopathology 94:1331-1336

Perchepied L, Dogimont C, Pitrat M (2005) Strain specific and QTL involved in the control of partial resistance to Fusarium oxysporum f. sp. melonis race 1,2 in a recombinant inbred line population of melon. Theor Appl Genet 111:65-74

Pitrat M, Risser G, Bertrand F, Blancard D, Lecoq H (1996) Evaluation of a melon collection for disease resistances. Cucurbits towards 2000. In: Proceedings of the VIth Eucarpia meeting on Cucurbit genetics and breeding. May 28-30 1996, Málaga, Spain, pp 49-58

Puhalla JE (1985) Classification of strains of Fusarium oxysporum on the basis of vegetative compatibility. Can J Bot 63:179-183

Quiot JB, Douine I, Gebre-Selassie K (1979) Frequence des principales viroses identifiées dans une exploitation maraichère de Sud-Est de la France. Ann Phytopathol 11:283-290

Risser G (1987) Controversy on resistance to Fusarium wilt in 'Perlita' (Cucumis melo L.). Cucurb Genet Coop Rep 10:60-63

Risser G, Rode JC (1973) Breeding for resistance to Fusarium oxysporum f. sp. melonis In: Risser G (ed) Eucarpia: La selection du melon. INRA, Montfavet, Avignon, France, pp 37-39 
Risser G, Mas P, Rode JC (1969) Mise en évidence et caractérisation d'une quatrième race de Fusarium oxysporum $\mathrm{f}$. sp. melonis. 2ème Congrès de l'Union phytopathologique Méditerranéene. Ann de Phytopathol 1:217-229

Risser G, Banihashimi Z, Davis DW (1976) A proposed nomenclature of Fusarium oxysporum f. sp. melonis races and résistance genes in Cucumis melo. Phytopathology 66:1105-1106

Robertson A (1989) Understanding the relationship between qualitative and quantitative genetics. In: Helentjaris $\mathrm{T}$, Burr B (eds) Development and application of molecular markers to problems in plant genetics. Cold Spring Harbor Laboratory Press, New York, pp 81-88

Schena L, Nigro F, Ippolito A, Gallitelli D (2004) Real-time quantitative PCR: a new technology to detect and study phytopathogenic and antagonistic fungi. Eur J Plant Pathol 110:893-908

Schreuder W, Lamprecht SC, Holz G (2000) Race determination and vegetative compatibility grouping of Fusarium oxysporum f. sp. melonis from South Africa. Plant Dis 84:231-234

Schroeder DT, Gordon TR (1993) An assessment of the relatedness of subpopulations within Fusarium oxysporum $\mathrm{f}$. sp. melonis based on DNA fingerprinting. Phytopathology 83:1346-1347 (Abstract)

Sestili S, Polverari A, Luongo L, Ferrarini A, Scotton M, Hussain J, Delledonne M, Ficcadenti N, Belisario A (2011) Distinct colonization patterns and cDNA-AFLP transcriptome profiles in compatible and incompatible interactions between melon and different races of Fusarium oxysporum f. sp. melonis. BMC Genomics 12:122

Sherf AF, Macnab AA (1986) Fusarium wilt of muskmelon. In: Sherf AF, Macnab AA (eds) Vegetable diseases and their control, 2nd edn. Wiley, New York, pp 334-337

Shlevin E, Mahrer Y, Kritzman G, Katan J (2004) Survival of plant pathogens under structural solarization. Phytoparasitica 32:470-478

Snyder WC, Hansen HN (1940) The species concept in Fusarium. Am J Bot 27:64-67

Tamietti G, Valentino D (2006) Soil solarization as an ecological method for the control of Fusarium wilt of melon in Italy. Crop Prot 25:389-397

Tezuka T, Waki K, Yashiro K, Kuzuya M, Ishikawa T, Takatsu Y, Miyagi M (2009) Construction of a linkage map and identification of DNA markers linked to Fom-1, a gene conferring resistance to Fusarium oxysporum f. sp. melonis race 2 in melon. Euphytica 168:177-188

Tezuka T, Waki K, Kuzuya M, Ishikawa T, Takatsu Y, Miyagi M (2011) Development of new DNA markers linked to the Fusarium wilt resistance locus Fom-1 in melon. Plant Breed 130:261-267
Thomas CE (1986) Downy and powdery mildew resistant muskmelon breeding line MR-1. Hortic Sci 21:329

Van Leeuwen H, Garcia-Mas J, Coca M, Puigdoménech P, Monfort A (2005) Analysis of the melon genome in regions encompassing TIR-NBS-LRR resistance genes. Mol Gen Genomics 273:240-251

Veloso MM, Melo EMPF, Jorge-Silva ML, Bravo MA (2000) Genetic diversity in Fusarium oxysporum f. sp. melonis. EPPO Bull 30:195-197

Wang YH, Thomas CE, Dean RA (2000) Genetic mapping of a Fusarium wilt resistance gene Fom-2 in melon (Cucumis melo L.). Mol Breed 6:379-389

Wang S, Yang J, Zhang M (2011) Developments of functional markers for Fom-2-mediated Fusarium wilt resistance based on single nucleotide polymorphism in melon ( $\mathrm{Cuc}$ umis melo L.). Mol Breed 27:385-393

Wechter WP, Whitehead MP, Thomas CE, Dean RA (1995) Identification of a randomly amplified polymorphic DNA marker linked to the Fom-2 Fusarium wilt resistance gene in muskmelon MR-1. Phytopathology 85:1245-1249

Zheng XY, Wolf DW (2000) Development of a SCAR marker associated with Fusarium wilt resistance and the evidence of its segregation with the Fom-2 gene in melon (Cucumis melo L.). Subtrop Plant Sci 52:1-7

Zheng XY, Wolff DW, Baudracco-Arnas S, Pitrat M (1999) Development and utility of cleaved amplified polymorphic sequences (CAPS) and restriction fragment length polymorphisms (RFLPs) linked to the Fom-2 Fusarium wilt resistance gene in melon (Cucumis melo L.). Theor Appl Genet 99:453-463

Zink FW (1983) Reaction of muskmelon germplasm to inoculation with Fusarium oxysporum f. sp. melonis race 2. Plant Dis 67(11): 1251-1255

Zink FW, Gubler WD (1985) Inheritance of resistance in muskmelon to Fusarium wilt. J Am Soc Hortic Sci 110(5):600-604

Zuniga TL, Zitter TA (1993) A new race of Fusarium oxysporum $\mathrm{f}$. sp. melonis causing wilt of muskmelon in New York. Phytopathology 83:1344 (Abstract)

Zvirin T, Herman T, Brotman Y, Denisov Y, Belausov E, Freeman S, Perl-Treves R (2010) Differential colonization and defence responses of resistant and susceptible melon lines infected by Fusarium oxysporum race 1,2. Plant Pathol 59:576-585 